\title{
Impact of the International Crises on the External Trade of Kashmir (1870-1947 A.D)
}

\author{
Brijish Jahan', Parvez Ahmad² \\ ${ }^{1}$ Government Degree College Tangmarg, Baramulla, Jammu and Kashmir, India \\ ${ }^{2}$ HistoryUniversity of Kashmir, Srinagar, Jammu and Kashmir, India \\ Email: brijishjahan@gmail.com,drparvezku@gmail.com
}

How to cite this paper: Jahan, B., \& Ahmad, P. (2020). Impact of the International Crises on the External Trade of Kashmir (1870-1947 A.D). Open Journal of Social Sciences, 8, 171-192. https://doi.org/10.4236/jss.2020.810012

Received: July 1, 2020

Accepted: October 23, 2020

Published: October 26, 2020

Copyright (c) 2020 by author(s) and Scientific Research Publishing Inc. This work is licensed under the Creative Commons Attribution International License (CC BY 4.0).

http://creativecommons.org/licenses/by/4.0/ (c) (i) Open Access

\begin{abstract}
War destroyed the communities and families in Europe and disrupted the developments of the social and economic fabric. But there were countries/regions which were not directly involved in these wars, had to face the same impact. For example, Kashmir situated on the fringes of the Indian sub-continent was equally affected by these International Crises. With the completion of Jehlum Valley Cart Road in 1890, trade increased manifold with Europe. But unfortunately, the involvement of European countries in war from 1870-1945 A.D, reduced the demand of highly praised luxurious items of Kashmir viz. Shawl, carpets, papier-mache, woodcarving, embroidery, woolens, silver item etc. Engagement of these governments in the gigantic war efforts: in which the whole economic activity was directed towards war industries, Kashmir while heavily relying on the foreign countries for its trade had to suffer.
\end{abstract}

\section{Keywords}

Artistic Excellence, Trade, Demand, Imports, Exports, Market, War, Decline

\section{Introduction}

The state of Jammu and Kashmir is situated at a place on the globe where the borders of half a dozen countries meet (Bazaz, 2003). From the immemorial times, the state people had established trade relations with their entire neighbouring world and were driving great benefit from them. Routes connecting trade centers of the state with those of the bordering countries had been opened. Before any roads for wheeled traffic were constructed, canals and rivers were also used for carrying merchandise from one place to another. It was natural that the people of Kashmir should have greater business intercourse with the coun- 
try, which was connected with the state through these waterways. The main big rivers of Jammu and Kashmir are/were Sind, Vitasta, (Cunningham, 1977), Chenab and Ravi. The source of these rivers is/was the big mountain ranges of Himalayas lying to the North and East of Kashmir and all of them flow into the West Punjab.

Kashmir did not have any modern highways till 1890 (Ahmad, 2007). The year 1890-1891, was a land mark in the history of Kashmir as it was, in this year that the construction of Jehlum Valley Cart Road was started (Administrative Report, 1892-1893). It was the opening of the Jehlum valley Cart Road which helped to diminish the isolation of the city from outside influences (Khan, 1999) plus Journeys to Srinagar by the English officers, travelers and missionaries became faster and more frequent (Census of India, 1941).

Jhelum valley road being the shortest line of communication between the valley, Hazara and the Indus, the route through the Jhelum valley below Baramula was used from ancient times. Hieun Tsang and Ou-Kong coming from Gandhara and Hazara followed this route on their way to Kashmir, and it was well known to Alberuni.

But on the other hand, the same road also brought the threat of competition. Srinagar's artisans were now faced with great competition outside. It came even more directly connected to the foreign as well as Indian markets. Kashmir that was heavily relying on the foreign countries for its manufacture of goods had to suffer. During the War periods the main exports of Kashmir especially shawls, Carpets Silk, woollens, papier mache, silver-ware, wood-carving and numdas etc. did not receive a good demand. The below discussion will help us in understanding that how these wars in Europe had direct bearing on the state of Jammu and Kashmir, which was neither the direct participant in the war nor ally of any European power during these wars.

1) Franco-Prussian war 1870-1871 A.D:

The First war which directly affected the shawl industry (Vigne, 1842) of Kashmir was Franco-Prussian war of 1870-1871 A.D; it resulted in the decline of this beautiful and classic industry of Kashmir. Shawl manufacturing industry is said to be "as old as the hills of Kashmir" (Census of India, 1921a) but it had practically died during the later Hindu period. Its revival towards the close of the $14^{\text {th }}$ century A.D is attributed to Sayyid Ali Hamdani (Hassan, 1959) who visited Kashmir in 1379 A.D He left for Turkistan via Ladakh after a stay of two years i.e. in 1381 A.D, on his way along snowy mountains of Ladakh, he was provided with socks made of pashmina wool or pashm. The soft and warm wool attracted his attention and therefore, on his return he took some wool to Srinagar where he presented it to the Sultan Qutab-ud-Din (1374-1389 A.D) who got it manufactured into a shawl (Jammu and Kashmir publication, 1954). However, the use of the word, "shawl" to represent woolen garment became popular during the reign of Mirza Hyder Doughlat (1540-1550 A.D) (Hussnain, 2004). It was not until the Mughal period (1585-1758 A.D) (Bamzai, 1980), that the industry achieved its full potential (Bernier, 1826). On the eve of the Mughal occupation 
of Kashmir in 1586 A.D. shawl industry had not only been extensively established but the industry had attained a high degree of perfection. According to Mughal chronicler, there were two hundred factories for making shawls (Wani Mohammad, 1998) and were exported to various countries of the world. The shawls of Kashmir were given the name of Param Naram by Emperor Akbar. Jahangir says that they are so excellent that there is no need to praise them ( $\mathrm{Ha}$ jat Ba Tariff Naist). He also made shawls one of favorite components of dress. The delicate texture, softness and durability had made Kashmiri shawls unrivalled in the whole world making them extensive article of trade. To quote Abul Fazl "the Kashmiri shawls are exported to ever clime" (Fazl, 1974).

Bernier, who visited Kashmir in the company of Aurangzeb in 1665 wrote:

"What may be considered peculiar to Kachemira, and the staple commodity that which particularly promotes the trade of the country and fills it with wealth, is the prodigious quality of shawls which they manufacture and which gave occupation even to the little children".

In 1796 A.D. during the time of Abdullah Khan, an Afghan Governor of Kashmir, a blind man, named Sayid Yahaya, had come from Baghdad as a visitor to Kashmir, and when he took leave from Abdullah Khan to return, the latter gave a present of orange-coloured shawl. The Sayid, having gone to Egypt gave it as a present to its Khedive there. Soon after, Napoleon Bonaparte came to Egypt with his famous fleet with the object of harassing the English in India, but he was smashed up by Nelson on the Nile. The Khedive gave him this shawl as a present. Napoleon sent it to France and it attracted the fashionable people there. French traders soon came to Kashmir to indulge in the trading activities of shawl and exported shawls of various designs to France.

In-fact France became the major consumer of this pride product of Kashmir, as is evident from the following Table 1 :

Table 1. Export of shawls to foreign countries.

\begin{tabular}{cc}
\hline Country & Percentage (\%) \\
\hline France & $80 \%$ \\
U.S.A & $10 \%$ \\
Italy & $5 \%$ \\
Russia & $2 \%$ \\
U.K & $1 \%$ \\
Germany & $1 \%$ \\
\hline
\end{tabular}

Source: Bates (1980), A Gazetteer of Kashmir, Kishtwar, Badrawar, Jammu, Noashera, Punch and the Valley of Kishan Ganga, Light and Life Publishers, New-Delhi, p. 59.

Besides, the Indian sub-continent shawls exported to Armenia, Central Asia, Afghanistan and Russia at the time of Moorcroft's visit (1823). The trade was mostly in the hands of the merchants from Turkey, Armenia, Persia, and Afgha- 
nistan. At the time of Moorcroft, much of the shawl trade was carried with Russia through Turkistan where shawls were in considerable demand. Persia was another important country which exercised considerable demand of Kashmir shawls. While visiting Persia Mohan Lal Kashmiri found the ruler of Persia desirous to conquer Kashmir simply because he was overwhelmed by the gracious art of its embroidered shawls (Maskiell, 2002). Andelphinstone, says "the king of Persia forbade the use of Kashmir shawls with a view to promote the shawl industry of his own country".

According to Young Husband: from 1862-1870, the export of shawls averaged 25 to 28 lakhs of rupees per annum, or over a quarter of a million sterling, and when the trade was at its zenith 25,000 to 28,000 persons were engaged in its manufacturing. In-fact France was the major importer of this pride product of Kashmir. This amounted simply to the high cost for the Kashmiri shawls, even a single piece of shawl was sold even at a fabulous price of Rs.12,500 in those days.

Simultaneously, Europe witnessed some drastic changes that not only left their impact on Europe but on the whole world. The foundation of the German Empire was the most important event in the European history during $19^{\text {th }}$ century (Roopshikha, 2008). The result of the unification was creation of German empire that enabled Prussia to control all the German states and European politics as well. The birth of Germany created an entirely new centre of gravity in international affairs and represents as complete a break with the Europe (1815-1871) as that Era represents a break with the ancient regime of Pre-French revolutionary days. Fundamentally, the cause of the Franco-Prussian conflict was the deep rivalry between the two countries which had revealed it in 1866 . There were bitter memories left by the first Napoleon; and there was the long historical grudge demanding satisfaction against Gallic neighbor who had kept Germany weak and divided for her own aggrandizement. France had long enough withheld from Germany her national right to development, and asserted outrageous and intolerable claim to interference. The startling growth of Prussian power and the unexpected demonstration of her strength had given to Europe and more especially to France, an unmistakable challenge (Grant and Temperely, 1927).

On $19^{\text {th }}$ July 1870, the French Emperor declared war to Prussian kingdom Napoleon III lead the Army. France weakened by its preceding wars (Crimea, Italy, Mexico) had an army of hardly two hundred thousand men on frontier against five hundred thousand men of Germany. Without any obstacle on their way, the German army invaded the region of champagne and finally reached Paris (Marriot, 1945).

It was because of this war France lost nearly 17,000 "communes" whole Alsace and part of Lorraine. It represented the loss of 1,600,000 men: moreover, under the terms of the Treaty of Frankfurt, France had to pay an indemnity of 5 billion gold francs plus the interests of 567 million francs to the German winner. To guarantee that payment, the enemy stationed troops and occupied some French 
departments for two years. During this period the French army got the right to station in the Loire. France cried over 138,000 killed people, prestige in the world and on her economy, which shattered completely by this war.

This war had come with misfortunes not only for people of France, or shattered its economy completely, but also had a deep impact upon the social and economic conditions of the people of the princely state of Jammu and Kashmir situated quite far away from her, as France alone accounted for the $80 \%$ of shawl exports from Kashmir by that time. The impact of this war had its adverse effect on the Kashmiri shawl as is evident from the fact that there remained only 5148 shawl bafs against 28,000 as per the Census Report of 1891 .

\section{2) Russian Expansion in Central Asia:}

Kashmir had been the meeting place of the three Greatest Empires (Yasin, 2002) of the East-the British, the Russians and the Chinese (Kapur, 1992). It was her strategic location which helped her in developing its trade relations with China, Central-Asia, Tibet, Yarkand, Kashgar and Russia etc. and it was carried on by the Treaty Highway Road. This road gave a unique commercial importance to the state which was recognized by the Government of India. The road connected the British India with Yarkand by the Karakoram pass (Knight, 1986) and formed an important trade route between India and Central Asia. The Genesis of this branch of trade lay in a Treaty (1842) signed between the Government of Tibet and Ladakh, represented by Raja Gulab Singh. Sometimes before the latter was conquered by the Sikhs in 1834. Kashmir assumed considerable significance as an enterpot of transit trade owing to its geographical contiguities with Central Asia and its linkage with the "Old Silk Route". The passes leading to the Central Asian plains through the Kabul valley also formed important lines of communication with Kashmir. The road from the valley followed closely the course of the Jehlum and after crossing the Urusha (Hazara) District, joined the caravan route from India. It was over this route, which makes the "Western Gate of Kashmir" that Hieun Tsiang and Ou'kung travelled to reach the valley. No doubt the External trade of Kashmir was largely carried through the aforementioned trade route network, but, owing to various political and other reasons the road from Srinagar to distant Yarkand and Lhasa was often blocked by snow resulting in the severance of the life-lines of commerce though temporarily. However, the demand of Kashmiri products was so strong and intimate that the merchants took roundabout and difficult tracks to reach Tibet or Central Asia (Kapur, 1992).

It is important to mention here that since the nature (composition) of Kashmir's External trade was largely determined by volume-value ratio (as these were snow bound areas so products which were less in weight, but high in demand were preferred by merchants to carry on these routes) of the commodities, therefore, Kashmir shawl became a preferable item of this trade. It is also important to put it here that the commerce of Ladakh was yet not of any value as far as her local production was concerned. The Foreign Trade of the area was 
confined to five natural productions, such as Wool (Bates, 1980) Salt, Dry fruits (apricots), Borax and Sulphur. But its importance consisted mainly in its being the entre pot of International trade. The Central Asian merchandise was housed in Ladakh and then supplied to Indian and Kashmiri merchants. Likewise most of the Central Asian traders received Indian and Kashmiri trading commodities through the merchants of these countries stationed in Ladakh. Cunningham, who visited that territory, gives a detailed list of articles imported and exported to China via Ladakh.

\section{Imports:}

Shawl-wool, Charas, Sliver, Felts, Tea, Russian Leather, Velvets, Coarse silk, Gold, Turquoises, Carpets from Khotan, Rewand-i-Chini, Coral Musk, Tobacco, Raisins and other Dry Fruits, Badam-i-Kitai, Mamira, Ponies and Salt.

\section{Exports:}

Cotton, Chintzes, Silk, Shawls, Jamiwars, Brocades, Opium, Heron-Plumes, Turmeric and other Indian Spices.

Times sometimes move fast than expected. It was in the second half of the Nineteenth century that Tsarist Russia and Britain found themselves in the state of rivalry in Central Asia, they had conflicting interests in the Balkan region of Europe. Each country tried to check the other extensions of power and influence in that direction. Russia had an alternate field to compensate her setbacks in the Balkan region, viz., Central Asia. In fact, she had been advancing towards Central Asia since the beginning of $19^{\text {th }}$ century. In this regard, William Moorcroft had written a warning in 1822 that trade with Russia via Turkestan was increasing. It was in 1832, the British East India Company Board of Control had sent Burnes to Central Asia to investigate the possibility of British commerce to counter a possible Russian threat to India. It was during this period, according to C. Karpinski "Russia imported more than two million rubles worth of Turkish and Kashmir shawls in 1825-1826". These moves of British in Central Asia affected the supply of shawl wool to valley. In the time of the Dogras, the average import of wool amounted to nearly 300 maunds. The following Table 2 shows the gradual decrease of the shawl wool.

Table 2. Shawl wool from central Asia to Kashmir.

\begin{tabular}{cc}
\hline Year & Maunds approximately \\
\hline 1658 to 1753 & 6000 \\
1753 to 1819 & 4000 \\
1819 to 1847 & 3200 \\
1867 to 1868 & 408 \\
1868 to 1869 & 707 \\
1869 to 1870 & 548 \\
1870 to 1872 & 300 \\
\hline
\end{tabular}

Source: Bates, 1980. A Gazetteer of Kashmir, Kishtwar, Badrawar, Jammu, Naoshera, Punch and the Valley of the Kishen Ganga, Light and Life Publishers, New Delhi, p 89. 
As shown in the table, from 1658-1753, 6000 maunds of shawl wool were imported by state for the manufacturing of shawls. From 1753-1872, a declining trend was seen in the import of shawl wool, from 1752-1819, 4000 maunds were imported, it further reduced to 3200 maunds in 1819-1847, in 1867-1868, only 408 maunds of shawl wool was imported, from 1868-1869, a slight increase was seen from 408 maunds, it rose to 707 maunds, but it fell again in 1869-1870 to 548 maunds. From 1870-1872 only 300 maunds were imported to the valley for its shawls.

The decrease in the imports was mainly due to:

1) Epidemics amongst the shawl wool goats in Turfan, Khotan, Yarkand and Kirghiz herds (Moorcroft \& Trebeck, 1841).

2) The heavy taxes levied on import of pashmina.

3) Sudden price rise of wool owing to its purchase by the British trading Company in India.

4) Increasing demand for wool from Delhi, Lucknow, Amritsar, Ludhiana and Rampur.

5) Emergence of Nurpur, Simla and Hosharpur as new centers of pashmina Trade.

6) The beginning of the shawl wool trade by the British merchants stationed at Darjeeling.

7) Impediment caused by the border conflicts between Kashmir and China on account of disturbed conditions in Sinkiang.

8) Last but not the least, tax exemption and other trade concessions granted to the Russians merchants by the Chinese government.

Moreover, Russia also made all efforts to consolidate its position in Western Turkistan. The rivalry between these two powers reached to the extent that British goods could not find its market in Russian dominated areas, including goods from Kashmir. Consequently, there was an urgent need to strengthen the British defenses on the North West of India. And the strategic position of Kashmir in the defense of the North West frontiers gave it a great importance. According to Wakefield:

In its relation to our rule in India the position of this kingdom, its physical and other characters, have an importance which its extent and general barrenness would scarcely warrant, for it constitutes a formidable defense, A Rocky Bulwark to our Empire on its Northern Frontier, a natural obstacle against any foe proceeding that quarter (Wakefield, 1879).

By watching these happenings, The British government took effective steps in the consolidation of the "Scientific Frontier" of the Indian empire. They extended railway lines up to Quetta and the Khyber passes. A policy of reconciliation with the Amir of Afghanistan was enunciated so as to secure safe North Western frontier. Having done this, they desired to seal two other doors from outside influence i.e. Gilgit and Leh (Kapur, 1992).

But these measures did not give a fruitful result as Russians also took a num- 
ber of measures in 1880 to exclude British-Indian commodities from Central Asian market (Hamilton, 1906). In 1888, the Russians established a consulate in Bukhara, which among other things, was to deal with matters relating to Afghanistan and by 1892 the Russian customs frontier was extended to the Afghanistan-Bukhara border. British used to give much importance to trade with Central Asia. Nothing a considerable increase in this trade was from 1894-1895. By 1895, the flow of British Indian goods into Central Asia through Afghanistan and Bukhara had declined by $80 \%$ severely damaging the position of Afghanistan in the transit trade (Hamilton, 1906).

It is pertinent to mention here that the balance of trade between Kashmir and Central Asia was heavily in favour of Central Asia. A little amount of woolen articles like Shawls, Gabbas and Carpets were seldom export. Iron and a few article of merchandise of daily use formed the exports. The annual Trade Report of 1900-1901 shows a surprising amoint of export trade from Kashmir to central asia which amounted to 16,697 maunds valuing Rs. 636,108. Thereafter the records available present a very low and poor profile of the same trade which is clear from the following Table 3 (Trade Report, 1907-1914).

Table 3. Export from Kashmir to Central Asia.

\begin{tabular}{ccc}
\hline Year & Quantity in Maunds & Value in Rupees. (Rs) \\
\hline $1907-1908$ & 106 & 392 \\
$1908-1909$ & 89 & 1925 \\
$1909-1910$ & 406 & 17,902 \\
$1910-1911$ & 175 & 862 \\
$1911-1912$ & 90 & 886 \\
$1912-1913$ & 12 & 635 \\
$1913-1914$ & 353 & 6067 \\
\hline
\end{tabular}

Source: Trade Reports of 1907-1914.

The trade between Kashmir and Central Asia was mostly an import trade, there is no export trade worth the name (Administrative Report, 1912-1913). The Central Asian traders who brought their articles to sell in Kashmir took off certain articles when they returned home (Trade Report, 1908-1909). Rations and personal luggage of the traders and travelers were registered under this head (Trade Report, 1911-1912).

With the Russian expansion in Central Asia and their constant rivalry with British, the trade relations between Kashmir and Central Asia, China got a setback. The Imperial designs of the two competing powers left the Kashmir on adverse receiving end, as a result of the closer of its trade routes.

\section{3) First and Second World War:}

The consequences of the First and Second World Wars resulted in mass destruction of cities and long lasting impact on both victorious and defeated coun- 
tries. But for those countries that were not directly involved in the war were also affected. Same was case with the state of Jammu and Kashmir which was quite far away from the war zone and was equally or even more affected by these wars. We see during this period the main exports of Kashmir especially Carpets Silk, woollens, papier mache, silver-ware, wood-carving and numdas etc. enjoyed a mixed demand. The below discussion will give us an idea of the same.

The carpet industry (Sufi, 1948-1849) is said to have flourished for a long time after Sultan Zain'l-Abidin's reign. The carpets of Kashmir, however, soon deteriorated. The modern craze for cheapness spoiled this as well as other works of art. An endeavour was made in time of Maharaja Ranbir Singh to improve the industry by involving Europeans. The contribution of C.M Hadow to the carpet trade was great. He sent Kashmir carpets for being exhibit in the big Chicago World Fair of 1890 A.D. The trade prospered and flourished. The year 1914 A.D, saw a great pressure on the carpet industry and as a result it expanded. Due to the availability of cheap labour and better technical guidance by the European entrepreneurs, the carpet industry prospered a lot. According to the Census Report of 1921, the six carpet industries located in the city of Srinagar gave employment to 1342 persons (Census Report, 1921). Women were not employed in the carpet factories. But a good number of women were employed as spinners for these factories who worked in their homes and were paid wages on contract basis.

Simultaneously, Silk (Khan, 1999) was also in great demand in foreign as well as in Indian markets. In 1901, sales in Europe amounted to Rs. 256,215 whereas in local market sales amounted to Rs. 8698 (Administrative Report, 1957). In 1902, the total European sales amounted to Rs. 266,215 and local sales amounted to Rs. 3763. During the following two years, the prices realized in England were 13 shillings and 14 shillings for first and second quality silk or (No. 1 and No. 2) (Ganju, 1945). In 1904, the factory came to have 10 filatures which contained 1864 reeling basins. In the same year, silk weaving was taken up on an experimental basis. Although the quality of cloth produced was satisfactory and found to compare favourably with the average products of the looms of Japan, but unfortunately, in 1907, a fire occurred in the Srinagar silk factory and almost all the stocks of silk were destroyed, as such nothing was exported out of the year's production (Administrative Report, 1969). It was also seen that new venture of experimentation did not prove successful from the financial point of view. Consequently, it was abandoned in 1909-1910. In the year 1912-1913, 1739 bales of Kashmir silk were sold in England during the year (Administrative Report, 1970). But in the year 1913-1914 there was a decrease in the out lays and the sales were confined to 1314 bales only (Administrative Report, 1971). In the year 1914-1915, the working of the department was seriously affected by the outbreak of First World War. The Europeans markets almost closed and the efforts to increase sales in India did not meet with much success. For this purpose some enquiries were made by Professor H. Maxwell, Imperial silk specialist, and E.C 
Ansorage, I.C.S, on behalf of the government of India to make complete survey of the position of the silk trade in India. Steps were also taken to make direct sales in the American markets.

Other industries like embroidered numdas got a great boost during the First World War. The export of numda after being embroidered in Kashmir ran into lakhs in the First World War. The demand for Kashmir woollens increased and decreased in the following manner. The demand of woollens in fact increased due to the ongoing "Swadeshi Movement." According to the available estimates, Kashmir by the years 1904-1905, 1905-1906 and 1906-1907 managed to export woolen (Ganju, 1945) weighing in total 5146, maunds 5819 maunds and 5339 maunds respectively. Once the movement petered out, the export figure came down to only 2977 maunds in and around the years 1913-1914. The position of the woollens fabrics exported during the different years of ongoing war becomes crystal clear through the information given in the below Table 4 and Table 5 (Trade Report, 1913-1918).

Table 4. Details of woolen exported between the years 1913-1918.

\begin{tabular}{cccc}
\hline S. No. & Years & $\begin{array}{c}\text { Weight of exported woolen } \\
\text { piece goods including shawl }\end{array}$ & Their appropriate value \\
\hline 1. & $1913-1914$ & 3203 & 263,355 \\
2. & $1914-1915$ & 4499 & 342,020 \\
3. & $1915-1916$ & 3340 & 248,290 \\
4. & $1916-1917$ & 8932 & 663,992 \\
5. & $1917-1918$ & 15,803 & 884,575 \\
\hline
\end{tabular}

Source: Trade Reports, 1913-1918.

The woollen exports retained its propitious marketing character up to the later part of the War, we see from 1913 to 1918 woollens showed increasing trend, because of the decline of the imports thence from, however they markedly fell which in turn bore considerable declining imprints on the prices as well. With this the imports swelled (Ganju, 1945). After the First World War, we find imports again increasing and exports decreasing. The extra labour which had found employment in the industry during the War period was thrown out there by the production had to be decreased. This adjustment took time. In the meantime goods were produced in excess of the demand and had to be sold at a lower price. This had its effects on the whole economy of the woollen industry, and the prices have gone down to a much lower level then they would have. If the production had been adjusted to the falling demand, immediately after the fall started. For want of adequate capital, labour and skill, the shawl industry could not take full use of the short lived effects of Swadeshi Movement of 1905. When the momentum of Swadeshi movement receded, the manufacture foreign goods again flooded the market and the demand for the handicrafts of Kashmir in general and the woollen goods in particular fell to low levels. 
Table 5. Details of woolen from 1918 to 1941.

\begin{tabular}{|c|c|c|c|}
\hline S. No. & Different years & $\begin{array}{l}\text { Weight of exported woolen piece goods } \\
\text { including shawls in (maunds) }\end{array}$ & $\begin{array}{c}\text { Their appropriate value } \\
\text { (Rs) }\end{array}$ \\
\hline 1 & 1918-1919 & 11,944 & 890,577 \\
\hline 2 & $1919-1920$ & 3855 & 619,339 \\
\hline 3 & $1920-1921$ & 3346 & 538,794 \\
\hline 4 & 1921-1922 & 2498 & 228,574 \\
\hline 5 & $1922-1923$ & 2440 & 695,959 \\
\hline 6 & 1923-1924 & 3716 & $1,104,660$ \\
\hline 7 & $1924-1925$ & 5795 & $1,766,365$ \\
\hline 8 & $1925-1926$ & 5128 & $1,301,226$ \\
\hline 9 & 1926-1927 & 1401 & 207,410 \\
\hline 10 & (Apr) 1927-1927 (Oct) & 4456 & 809,822 \\
\hline 11 & (Oct) 1927-1928 (Sept) & 4852 & 871,452 \\
\hline 12 & (Oct) 1928-1929 (Sept) & 9108 & 927,295 \\
\hline 13 & $1929-1930$ & 8746 & 925,150 \\
\hline 14 & $1930-1931$ & 5301 & 365,274 \\
\hline 15 & 1931-1932 & 7428 & 520,399 \\
\hline 16 & $1932-1933$ & 8858 & $1,288,631$ \\
\hline 17 & $1933-1934$ & 3294 & 467,170 \\
\hline 18 & 1934-1935 & 11,539 & 595,071 \\
\hline 19 & $1935-1936$ & 4689 & 472,035 \\
\hline 20 & 1936-1937 & 5021 & 595,683 \\
\hline 21 & $1937-1938$ & 5948 & 721,753 \\
\hline 22 & $1938-1939$ & - & 5665 \\
\hline 23 & $1940-1941$ & - & 15,080 \\
\hline
\end{tabular}

Source Trade Reports 1918-1941.

From 1918-1919, woolens contributed to Rs. 890,577 to state economy. But again there was declining trend in the sale of woollens from Rs. 890,577 it reduced to Rs. 695,959. From 1923-1925, a slight increase was seen from Rs. 695,959 to Rs. $1,766,365$ in the value of woollens but fell again to Rs. 365,274 in 1930-1931. After 1931-1937, woollens faced fluctuations in value because of low response of people to the boycott of British goods. In 1937-1938, woollens again shown revival in demand from Rs. 365,274 it reached to Rs. 721,753. Afterwards, the contribution of woollens to state economy was meager only Rs. 15,080 in 1941. No official records are available after 1941 till independence.

While as, on the other side, in 1939-1940, the total sales amounted to 191.584 lbs. of raw silk and 101,486 lbs. of silk wastes. Total receipts from the sale came to Rs. 1,125,430 (Administrative Report, 1995). The year opened with somewhat a depressed state of market and closed with distinctly hopeful prospects. The effects of the abnormal decline in the prices during the latter half of the preceding 
year continued to be felt in the early part of the year. But during closing months especially since the declaration of war improvements in the situation were substantially enough to counter balance the efforts of earlier depression (Administrative Report, 1995).

Handloom silks mostly depended on home markets. The War, therefore, did not interfere with its steady growth. More so because of the innovations of certain enterprising firms during the year 1939-1940, large quantities of Georgettes were produced. They swelled the volume of trade. Silk products were in great demand in the Indian cities, especially Lahore, Amritsar and Delhi. During 1940-1941, Bedsheets, Teapoy covers and Silk Sarees, particularly in embroidery form were in great demand. Of course, war did create a problem with respect to improvement in dyes and chemicals. Those who already possessed the stocks, indulged in profiteering. With all these difficulties the handloom industry was considered to be the biggest cottage industry in the state during 1943. Embroidery was also done on woolens and silks in Kashmir. It was an auxiliary of Woollens and Silk industries. Amlikar shawls had become famous all over the world because of the attractive work done on Pashmina or Raffal. Silk Saries, Teapoy covers, and Bedsheets were in great demand in 1941 because of the colourful designs in embroidery. Though, the price of Pashmina wool had gone up in 1942-1943. Yet the popularity of excellent embroidery motivated artisans to do more work and produce very beautiful pieces which could be acceptable even on higher cost. About 17,000 persons worked in this industry during 1940-1941. In 1942 the total production of carpets was estimated to 40,000 sq.ft valued at Rs. 1,200,000. Soon after the close of the Second World War the American demand shifted back from "numdas" to carpets and this increased the annual output. The home demand also increased. The restoration of normalcy in the state and the rapidly increasing tourist traffic increased the demand for carpets. The increasing demand of carpets helped the Kashmir in developing its economy.

Yet another active art of Kashmir during this period was papier-mache. During the period of War, the number of visitors to the valley showed a marked increase due to influx of army personal, who spent their holidays in Kashmir, the papier-mache industry, therefore made brisk sales and the total value of goods produced increased from Rs. 2 lakhs (Administrative Report, 1940-1941) in the year 1940-1941 to Rs. 2.5 lakhs in the year 1941-1943, about 600, people were employed in the industry during the year 1940-1941.

Inspite of the rise in the price of silver the turnover of the silverware industry increased tremendously. Because of the excellent finish and workmanship of the craftsmen, the demand for the silver-ware increased to the extent that it became difficult for the leading firms to cope with the demand with the existing workforce (Administrative Report, 1941-1943). The industry employed 1100 workers in the year 1941-1943 on the other hand; the brass and metal ware industry did not do well because the price of brass and another connected material had increased due to War.

Wooden furniture and wood carving (Census of India, 1921b) a well-known 
cottage industry of Kashmir continued to be popular during the War. The industry was able to meet the total requirement of the entire state. The toys produced in some of the towns of Kashmir were famous for their excellent shape, finish and colour. Improvement in the designs of the toys was under the considerations of the government at the end of 1943. Wood-caving also was popular and made brisk business at the annual exhibition at Srinagar among the tourists throughout the tourist season in Kashmir.

During the year 1940-1941, there was a marketed improvement in the prices of raw silk and silk wastes. All products of silk factories including the silk wastes remained in great demand. The market of raw silk improved owing to International Situation (Administrative Report, 1997-1998). In 1941-1942, as a result of the World War II, the prices of silk and wastes soared higher and higher. The demand for the products of silk factories rose to unexpected figures; simultaneously the prices of all silk supplies and services required by the department also rose considerably (Administrative Report, 1941-1943). The War condition greatly influenced the export trade of Kashmir silk during the year 1942-1943 A.D and 1943-1944. A.D (Administrative Report, 1945-1946). Major proportion of silk was supplied to the government of India for defense purposes during the period of International turmoil. This was done in response to an order placed by the British government of India with the Kashmir government for 125,000 lbs. of raw silks for parachute cloth. The price at which the silk was supplied was 16-3 per lbs. Total sales for Kashmir amounted to Rs. 184,950 during the second half of the year 1942 and 33,970 during 1943.

During the year 1944-1945 A.D, and 1945-1946 A.D, war conditions continued to influence the working of the industry in all respects. The department continued to supply to the government of India for defence purposes practically the whole of it's out-turned (Administrative Report, 1944-1945). Thus to give impetus to the local weaving industry local manufactures were also supplied with raw-silks at prices much below the markets rates. The outturn of superior silks was booked by His Majesty government and the inferior silks were sold in India markets. The sales of silk and it's by products effected by the department during the year 1945 totaled 241,759 pounds and the amount received was Rs. 38,339,415 (Administrative Report, 1998-1999).

We see the ups and downs in the market continued till the Second World War was over except silk; no product of Kashmir was used for war purposes.

\section{4) Closure of Jehlum valley road:}

Kashmir did not have any modern highways till 1890 (Ahmad, 2007). The year 1890-1891, was a land mark in the history of Kashmir as it was, in this year that the construction of Jehlum Valley Cart Road was started (Administrative Report, 1923-1924). It was the opening of the Jehlum valley road which helped to diminish the isolation of the city from outside influences plus Journeys to Srinagar by the English officers, travelers and missionaries became faster and more frequent (Census of India, 1941). 
Jhelum valley road being the shortest line of communication between the valley, Hazara and the Indus, the route through the Jhelum valley below Baramula was used from ancient times. Hieun Tsang and Ou-Kong coming from Gandhara and Hazara followed this route on their way to Kashmir, and it was well known to Alberuni.

The Jhelum valley road below Baramula is confined between two ranges of mountains - the one to the south being a branch of the Pir-panjal and the other to the north of Kajinag. These two ranges accompany the course of the river with gradually lessening height for about 80 miles to a point near Muzaffarabad where the Jhelum makes its sudden bend to the south. The valley is throughout narrow and the rout leading along it must have always been troublesome and risky in olden times. It is perhaps due to this reason that we hear comparatively little about it in the Rajatarangni of Kalhana. The military and commercial importance of this route are lesser than that of Pir-panjal and Tosamaidan routes. It is only in modern times that this western route has attained a real prominence. This originated in the time of the Afghan rule over Kashmir, when the route along the Vitasta to Muzaffarbad and hence through Hazara afforded the shortest and least exposed line of communication between Kashmir and Peshawar (Stein, 2007). Subsequently, after the annexation of the Punjab, the establishment of the hill station of the Muree naturally drew traffic in this direction. The construction of the Tonga road from Muree to Baramulla finally assured to this route its present supremacy.

By the end of the $19^{\text {th }}$ century, Kashmir was hit by a severe famine in 1877-1879 (Civil and Military Gazette, 1878), which made it necessary to have a good road which could connect the valley with the Punjab, from where the grains for relief could be imported (Younghusband, 1996). The plan took a practical shape, when the construction of the said road was undertaken in 1881, for a cart road from Baramulla (Neve, 2003) to Kohala by the state government. Its length was about $97 \frac{1}{2}$ miles of which only 25 miles were nearly completed in 1885. In other words, the work was being executed at the average rate of about 6 miles a year. At this rate, about 11 more years were needed to construct the whole road. The chief reason for such a slow progress was stated to be the lack of funds with the state government (Kapur, 1992).

Another reason which made the construction of road important was at this time, the British government of India was greatly alarmed by the Russian advance in Central Asia. In the words of col. Algernon Durand:

She had advanced practically to the Hindukush; it was necessary to see that she did not cross it (Tyndale Biscoe, 2004).

Such then became the determination of the government of India. And to facilitate the achievement of that objective, they decided that, not only the construction of a road from India to Kashmir, whose borders touched those of the Russian Turkistan, should be completed (Knight, 1986), but a road even beyond up 
to Gilgit and Chitral should be speedily improved.

Consequently, in 1888, col. Parry Nisbet was sent to Kashmir as British Resident and he assisted the state in accomplishing the desired end. It was pushed forward with greater zeal, when the contract was made over to a British firm of contractors, Spedding Mitchel and Co; who brought the work to a completion in a record time. The road was opened for wheeled traffic in 1890, when Maharaja Pratap Singh was driven through from Baramulla to Kohala on the borders of his state. But it was not yet completed (Administrative Report, 1891-1892). The road was further extended from Baramulla to Srinagar in 1893, and was completed at the end of 1895 (Administrative Report, 1894-1895). It touched the city of Srinagar at Amira Kadal. Its length from Srinagar to Kohala was 132 miles. Thereafter, it led to Rawalpindi while crossing over the Muree Hills. The travel became very comfortable and easier for passengers in Tongas, Ekkas and then by the Motorcars. The distance of months was covered in a day to six days i.e. one day by motorcar, two days by Tongas and six days by Ekkas. From Srinagar to Rawalpindi its distance was 196 miles. The road was spoken of as a masterpiece of mountain engineering and was recognized by some as "the most beautiful Motorable road in the whole world". This road costs Rs. 2,178,780 which was a huge sum. But as a trade route the Jehlum valley road did not prove of any considerable importance until it was made fit for wheeled traffic (Ahmad, 2007). The road was one of the main trade routes of the state and almost whole of the trade between Kashmir and British India was carried on by this route (Trade Report, 1900-1901). It was then the border town of the Punjab province of the then British Indian territories was constructed. The significance of this road was highlighted by Ernest, F Neve in these words:

According to him the chief exports are fruits, consisting largely of apples, pears, and walnuts. Of this over, 100,000 maunds, or about 3500 tons are exported annually. Rice and maize vary between one thousand and three thousand tons, according to the existence of scarcity in the North of India. Linseed, ghee, potatoes, hides wool, woolen cloth are all exported in large quantities. The value of the silk sent out of Kashmir annually amounted alone to over 100,000 sterling's and the timber which is floated down the river to the Punjab represents fifty to eighty thousand pounds sterling a year (Neve, 2003) (Table 6).

Table 6. Exports from Kashmir to Punjab and other parts of world.

\begin{tabular}{ccc}
\hline YEAR & QUANTITY IN MAUNDS & VALUE IN RUPEES \\
\hline $1898-1899$ & 175,575 & $2,110,869$ \\
$1899-1900$ & 208,585 & $1,922,673$ \\
$1900-1901$ & 398,450 & 249,903 \\
$1901-1902$ & 371,177 & $2,729,092$ \\
\hline
\end{tabular}




\section{Continued}

\begin{tabular}{|c|c|c|}
\hline 1902-1903 & 392,362 & $4,656,241$ \\
\hline 1903-1904 & 278,422 & $5,250,194$ \\
\hline 1904-1905 & 204,141 & $3,492,212$ \\
\hline 1905-1906 & 698,372 & $4,384,392$ \\
\hline 1906-1907 & 883,141 & $5,388,406$ \\
\hline 1907-1908 & 977,305 & $5,668,467$ \\
\hline 1908-1909 & 968,369 & $5,528,040$ \\
\hline $1909-1910$ & $1,000,602$ & $5,941,349$ \\
\hline 1910-1911 & 970,517 & $6,039,130$ \\
\hline 1911-1912 & 967,641 & $6,597,125$ \\
\hline $1912-1913$ & $1,848,842$ & $8,205,936$ \\
\hline 1913-1914 & $1,576,580$ & 665,712 \\
\hline 1914-1915 & $1,148,491$ & $8,205,935$ \\
\hline 1915-1916 & $1,058,575$ & $6,366,802$ \\
\hline 1916-1917 & $1,660,081$ & $9,982,682$ \\
\hline 1917-1918 & $1,347,406$ & $11,352,283$ \\
\hline 1918-1919 & $1,311,808$ & $11,886,666$ \\
\hline $1919-1920$ & $1,182,819$ & $8,907,625$ \\
\hline 1920-1921 & $1,251,513$ & $10,314,228$ \\
\hline 1921-1922 & $1,214,723$ & $9,266,302$ \\
\hline $1922-1923$ & $1,646,331$ & $12,491,140$ \\
\hline 1923-1924 & $1,485,479$ & $11,749,930$ \\
\hline 1924-1925 & $1,530,115$ & $13,512,653$ \\
\hline $1925-1926$ & $1,807,883$ & $13,430,290$ \\
\hline 1926-1927 & 1401 (woollen) & $2,848,137$ includes woollen and silk value \\
\hline $1927-1928$ & 4852 (woollen) & 4,135,857 (woollen and silk) \\
\hline 1928-1929 & 9108 (woollen) & 3,569,483 (woollen and silk) \\
\hline $1929-1930$ & 8746 (woollen) & 3,350,541 (woollen and silk) \\
\hline $1930-1931$ & 5301 (woollen) & 1,733,716 (woollen, silk and carpet) \\
\hline 1931-19v32 & 7428 (woollen) & 550,399 (woollen silk and carpet) \\
\hline $1932-1933$ & 8858 (woollen) & 2,038,631 (woolen, silk and carpet) \\
\hline $1933-1934$ & 3294 (woollen) & 122,517 (silk, woollen and carpe)t \\
\hline 1934-1935 & 11,535 (woollen) & $11,395,071$ (woollen and carpet) \\
\hline $1935-1936$ & 4689 (woollen) & $1,606,035$ (woolen and carpet \\
\hline $1936-1937$ & 5021 (woollen) & 595,683 \\
\hline $1937-1938$ & 5948 (woollen) & 721,753 \\
\hline $1938-1939$ & 35,550 (silk) & 5665 \\
\hline $1939-1940$ & 52,062 (silk) & $1,133,138$ \\
\hline
\end{tabular}


Continued

\begin{tabular}{ccc}
\hline $1940-1941$ & 97,149 (papier-mache) & 265,080 \\
$1941-1942$ & - & $1,100,000$ numdas \\
$1942-1943$ & 400,000 (sq.ft) & $1,384,950$ (silk and carpets) \\
$1943-1944$ & - & 33,970 silk \\
$1944-1945$ & - & $38,339,415$ silk \\
\hline
\end{tabular}

Source: Annual Trade Reports of J\&K state from 1898-1945.

Additional employment was also generated in bakeries, laundries, entertainment places, retailing trade, hotels, restaurants, cooks, bearers and other servants required to man theses places.etc. Considerable additional demand for food stuffs, vegetables, fruits, eggs, meat and milk was created which was met from local products. The visitors also bought local products which supported a large number of cottage and small scale industries engaged in making shawls, carpets, embroidery work, gabba, lois, woodcarving, jewelry, and papier machie articles. Thus, the impact on tourism on Kashmir in general and Srinagar in particular was fairly widespread and the employment created directly or indirectly through it was considerable.

Till 1947, there were three highways linking the state with the outside world. Besides, Jehlum valley road from Srinagar to Kohala via Baramulla and Domel; Banihal road from Srinagar to Sialkot via Banihal and Jammu; and Abbotabad road, from Domel to Abbotabad via Ramkot were linking valley with the outside world. There was also a rail link from Jammu to Sialkot forming part of the pre-partition North-West railways (Bazaz, 2003).

Besides these highways, there were several bridle paths and footpaths connecting different parts of the state (Ahmad, 2007) with neighbouring countries but such of them as could be maintained in good conditions were used in case of emergency or only by local people living on either side of the border (Bamzai, 1980). It will be seen that like the big rivers all the highways connected the Jammu and Kashmir state with that part of the Punjab, which now forms part of Pakistan. It was therefore quite natural that almost all export and import business of the country should be carried on with or through the trade centres of that province particularly Rawalpindi and Lahore. To do so was easier, cheaper and mutually beneficial. The timber weighing millions of tons grown in the far flung forests of Jammu and Kashmir was carried by the Punjab almost free of any charge. Fruits and other products were speedily taken from the orchards of the valley to Rawalpindi and disposed off within twenty four hours. Of all the seaports in India Karachi, city of Pakistan was nearest to Kashmir. It was and could be cheaper to get foreign goods into the state through this port.

In 1947, British rule ended in India and out of the undivided country two states were fashioned-India and Pakistan, the latter again being in two units of East and West Pakistan. The whole business of the abrupt termination of the British Indian Empire seems to have taken most of the rulers by surprise, and 
some were profoundly shocked by what they have considered to be British perfidy. Till the declaration of the independence by India and Pakistan on 15 Aug. 1947, the people of Kashmir state hoped that they too would enjoy freedom after 128 years of incessant slavery and suppression. They thought that Maharaja Hari Singh might agree to the compulsions of geographical contiguity and composition of population of the state and accede to Pakistan. But with the announcement of Radcliff award a different picture emerged. Kashmir became more susceptible than before to the pulls of rival dominions of India and Pakistan and was, therefore, due to suffer heavily in consequence (Pampori, 1992).

With the Decolonization of Indian sub-continent accompanied by partition and conflict between the two succeeding states of India and Pakistan the problems of the state of Jammu and Kashmir which had close and intimate contacts with both of them increased manifold, needless to say that the status of the state of Jammu and Kashmir was the bone of contention in that conflict (Gupta, 1967). Partition explained with different meanings by different authors. Few of these are produced here.

Sugata Bose and Ayesha Jalal, had explained in these words, That the dawn of independence came littered with the several limbs and blood drenched bodies of innocent men, women and children was a nightmare from which the sub-continent has never fully recovered. The colossal human tragedy of the partition and its continuing aftermath has been better conveyed by the sensitive creative writers and artists-for example in Saadat Hasan Manto's short stories and Ritwik Ghatak's films-than by historians (Bose and Jalal, 2004). Larry Collins further substantiated partition in these words that "Cyril Radcliff's ... line had left 5 million Sikhs and Hindus in Pakistan half of the Punjab, over 5 million Muslims in India's half dead". Mehar Chand Mahajan, in his book "Looking Back" observed that about 2 million people migrated from one side to the other (Mahajan, 1994). This situation was touched by another author, who said that ours has been a century where countries have been partitioned to fulfill the economic and political ambitions of formidable groups, completely ignoring the cost of human suffering, which has been enormous and continuous. Even in such callous and unpromising times the partition of the Indian subcontinent registered as an awesome tragedy (Settar and Gupta, 2002).

Partition was accompanied by several unfortunate circumstances for India in general and Kashmir in particular. There were problems which were associated with any such process of division. For instance, difficulties relating to the division of assets, and liabilities, demarcation of boundaries both of the land and the water. Several administrative difficulties emerged as one political unit had to be bifurcated.

After partition, the embroidery industry Sozni like other crafts received a setback, partly because of the division of the country, leading to a human tragedy and partly due to the attack on Kashmir by tribesmen (Birdwood, 2005). The 
road and railway links of the state were cut off. No tourists visited Kashmir due to disturbed conditions. This led to the losing of markets inside and outside Kashmir. The situation highlighted by Ian Talbot in his book in these words:

The protection and control of access of the movement of people and goods through borders is a vital symbol of statehood within weeks of the chaotic scenes of partition, the India and Pakistan states had tightened their grip of Attari and Wagah (Talbot, 2006). The experience of the colonial states war time system of controls was put into practice with the creation of an elaborate system of permits and licenses. State construction proceeded at the expense of the former free movement of people and goods between Lahore and Amritsar. While the order was an economic resource for some, it dealt a savage blow to others and Amritsari traders in particular became hostages to geography their city, cut off from its former markets and raw material supplies, was now dependent for its prosperity on government decisions concerning cloth quotas, import and export licenses and transport. A peripheral city that lacked administrative importance possessed only limited political leverage.

To make good the loss sustained by the state and its, people by this abrupt dislocation of export and import trade, the government of India constructed a new highway at a hugest cost of the three crores of rupee linking Jammu with pathankot in east Punjab. It was a marvelous feat of road engineering (highly creditable to the public works department of the government of India) the road is an extension of the Srinagar Banihal-Jammu road. Thus instead of the four water ways, three highways and one railway linking, the state with the outside world we have now one road and it was supposed that this would meet the demand of the people. As a matter of fact the National conference leaders in Kashmir have stated in their speeches and statements more than once that the business carried on through the Srinagar-Pathankot road is larger in volume than used to be conducted through all the abandoned highways, waterways and railway put together (Bazaz, 2003). No doubt, when the new government under the leadership of Sheikh Abdullah took over, they formulated a well considered policy for rejuvenating artisan industry in Kashmir. The first and foremost step which the government took was to provide market to the suffocating artisan industries. This they did by laying a network of emporiums throughout the country under Government Arts Emporium. Among other arts and crafts, Kashmir embroidery formed one of the most important crafts of Kashmir and was displayed and sold through these Emporia. The embroidery produced, in the production centers and purchased from private Karkhandars was sold through these Emporia's.

\section{Conclusion}

With the completion of Jehlum Valley Cart Road in 1890, life had become easier for the people of Kashmir in many ways, it increased employment opportunities 
in valley and also developed her trade relations with the other parts of the world especially Europe. Unfortunately, due to the absence of the reliable facts and figure it is very difficult to compare the situation after independence and before independence. The Maharajah's previous governments used to publish: statistics about all important matters in their Annual Administration Reports. Many heads of departments also were, as a matter of rule, giving comprehensive data about their working in their Periodical Reports. After independence no report was submitted so therefore it is not easy to know to what extent the Srinagar-Pathankot road has been able to make good the damage that has been done to the country by the sudden closure of her nature-given water-ways, expensively-built highways and wisely designed small and single railway. Yet it is also very difficult to see the irreparable loss that the state people have suffered by the new arrangements and will, continue to suffer until the closed waterways and high-ways and the railway will be re-opened and traffic on them re-started under normal and peaceful condition.

\section{Conflicts of Interest}

The authors declare no conflicts of interest regarding the publication of this paper.

\section{References}

Ahmad, P. (2007). Economy and Society of Kashmir, a Study in Change and Continuity (1885-1925) (p. 186). Srinagar: Oriental Publishing House.

Bamzai, P. N. K. (1980). Kashmir and Central Asia (pp. 28-29, 99). New Delhi: Light and Life Publishers. The Chak Rule in Kashmir Was Marked by Internal Feuds. This Led to the Mughal Occupation of Kashmir in 1586. Qasim Khan Was the First Mughal Governor of Kashmir.

Bates, C. E. (1980). A Gazetteer of Kashmir, Kishtwar, Badrawar, Jammu, Naoshera, Punch and the Valley of the Kishen Ganga (p. 89). New Delhi: Light and Life Publishers.

Bazaz, P. N. (2003). The History of Struggle for Freedom Kashmir (Cultural and Political from Earliest Time to Present Day) (p. 490). Srinagar: Gulshan Publishers.

Bernier, F. (1826). Travels in the Mughal Empire (1656-68) (pp. 401-403, 427). London: Oxford Publications.

Birdwood, L. (2005). Two Nations and Kashmir (p. 58). Srinagar: Gulshan Publishers.

Bose, S., \& Jalal, A. (2004). Modern South Asia, History Cultural, Political Economy (2nd ed., p. 158). Oxford: Oxford Press. https://doi.org/10.4324/9780203712535

Census of India (1921a). (Vol. XXII, Part II, pp. 180-181). References Are Found in Hindu Scripture Which Point to Its Great Antiquity. During the Epic Age This Industry Is Said to Have Firmly Established in the Kashmir Valley, and "Tradition Has It That When Krishna Went to Kaurvas as a Delegate from the Pandavas, the Present of Dhritrastra to Him Included 10,000 Shawls of Kashmir.

Census of India (1921b). (Vol. I, pp. 179-180, 183). Wood Work Is an Ancient Industry of Kashmir. It Also Received Due Attention during the Reign of Sultan Zain-ul-Abidin. The Main Types of Wood Work Found in Kashmir Were (i) Lattice or Pinjara Work, 
(ii) Paneling or Khatm Band, (iii) Carving of Wood, (iv) Furniture Making.

Census of India (1941). (p. 27).

Civil and Military Gazette (1878). p. 1. friend of India, 17 Sept., 1879.

Cunningham, A. (1977). Ladak, Physical, Statistical and Historical (p. 111). New Delhi: Sagar Publications. The Natives of the Country Called It the "Behut" or "Vehut"; an Older Name Still Used by Those of Them Who Follows Sanskrit Literature, Is Vitasta or Vidasta. Which the Greeks Slightly Altered to Hydaspes.

Fazl, A. (1974). 3 Volumes English (Tr) of Vol. I by Blochmann and the Two by H.S. Jarret Which Were Further Revised by Jadu Nath Sarkar (pp. 78-79). Delhi: Oriental Publisher.

Ganju, M. (1945). Textile Industry in Kashmir (pp. 155-156). Delhi: Premier Publishing House.

Grant and Temperely (1927). Europe in the Nineteenth and Twentieth Centuries (1789-1950) (p. 278). London: Longman Publishers.

Gupta, S. (1967). Kashmir: A Study in India-Pakistan Relationships (p. 30). Bombay: Asia Publishing House.

Hamilton, A. (1906). Afghanistan (pp. 288-298). London: W. Heinemann.

Hassan, M. (1959). Kashmir under the Sultan (p. 55). Srinagar: Ali Mohammad and Sons.

Hussnain, F. M. (2004). Heritage of Kashmir (pp. 180-181). Srinagar: Gulshan Publishers.

Kapur, M. L. (1992). Social and Economic History of Jammu and Kashmir State (1885 to 1925) (p. 34). New Delhi: Anmol Publications.

Khan, M. I. (1999). History of Srinagar (p. 35, 70). Srinagar: Cosmos Publications. The Mention of Silk Stuff Is Made for the First Time in Zain-ul Abidin's Reign.

Knight, E. F. (1986). Where Three Empires Meet (A Narrative of Recent Travel in Kashmir, Western Tibet, Gilgit, and the Adjoining Countries) New Edition (p. 131). New Delhi: Datta Book Center.

Mahajan, M. C. (1994). Looking Back (p. 94). New Delhi: Haran and Publication.

Marriot, J. A. R. (1945). European Common Wealth (pp. 184-187). London: Oxford University Press.

Maskiell, M. (2002). Journal of World History, University of Hawai Press, Vol. 13, No. 1, $p p, 27-65)$.

Moorcroft, W., \& Treback, G. (1841). Travels in the Himalayan Provinces of Hindustan and the Punjab, in Ladakh and Kashmir (Vol. 2, pp. 167-168). London.

Neve, E. (2003). Beyond the Pirpanjal (Life among the Mountain and Valley of Kashmir). (p. 43). Srinagar: Gulshan Publishers.

Pampori, M. S. (1992). Kashmir in Chains (p. 168). Srinagar: Pampori Publishing House.

Roopshikha, M. (2008). History of Europe (1870-1950) (p. 6). New Delhi: Murari Lal and Sons.

Settar, S., \& Gupta, B. I. (2002). Pangs of Partition, the Human Dimension (p. 59). New Delhi: Manohar Publishers.

Stein, M. A. (2007). Kalhana’s Rajatarangini (p. 402). Srinagar: Gulshan Books.

Sufi, G. M. D. (1948-1849). Kashir: Being a History of Kashmir from the Earliest Times to Our Own (2 Vols., p. 571). Lahore. History of Carpets Can Be Traced to the Earliest Traces of Human Civilization if Taken into Consideration in Its Crude Form. The Terracotta Tiles of the Earliest Period Excavated from Burzhama to Guphkral Bear to Imprints of Crude Mating. It is True about the Finds of Alabaster Slabs Found at the 
Place of Old Persian Cities of Senna Cherib and Assurbanipal; in the Loulan Deserts of Turkistan and in the Tomb of Cyrus. With the Advancement of Civilization the Weaving Were Improved upon. The Earliest Form of Crude Nomadic Carpet Like Overalls of the Pack Horses Called "Araq Gir" Is the First of Its Woven with Twisted Horses' Tail Hair and the Cotton Weft Simultaneously Was Inserted. Prof, Mattoo, A.M, Kashmir Carpet-An Appraisal in Ahmad Nazirs "Craft” A Magazine Devoted to Arts and Crafts of Jammu and Kashmir, 16 March, 1998, Jammu, p 10.

Talbot, I. (2006). Divided Cities, Partition and Its Aftermath in Lahore and Amritsar 1947-57 (p. 98). Oxford: Oxford University Press.

Tyndale Biscoe, C. E. (2004). Kashmir in Sunlight and Shade (p. 30). Srinagar: Gulshan Publishers.

Vigne, G. T. (1842). Travels in Kashmir, Ladakh, Iskardoo (Vol. II, p. 280). London: Colburn Press. Shawl Signifies a Kind of Very Soft and Delicate Woolen Fabrics of Kashmir Made from the Fleece of a Goat Reared Exclusively in the Mountainous Regions of Ladakh and Tibet. Al shal (Arabic). Shal (Persian), and Shawl (English). All Denote a Rectangular Piece of Woolen Cloth of Kashmir Worn on Shoulders. In Persian "ShaP' Also Means a Garment Usually Worn on Shoulders. In Sanskrit We Find Words Like Shalmai, Sal and Sala Which Respectively Mean "the Silk-Cotton Tree", to Shine, "Be Endowed with" and "Fence" and Indicate the Quality Which the Kashmir Shawl Is Famous for Throughout the World. Across the Northern Mountains of the Valley There Is the Land of Dards in Whose Language "sha" Means the Shawl-Wool Goat. Mr. Vigne Visited This Land in the $19^{\text {th }}$ Century and Found That the "Sha" Is a Tragelaphus, or Goat Dear, Which Furnishes Wool Profusely. It Is Most Probable the Origin of the Term Shawl Is in "Sha".

Wakefield, W. (1879). The Happy Valley (p. 12). Srinagar: Gulshan Publishers.

Wani Mohammad, A. (1998). Hey Days of Shawl Industry. In A. Nazir (Ed.), "Craft” A Magazine Devoted to Arts and Crafts of Jammu and Kashmir (p. 30). Jammu: Apollo Publishers.

Yasin, M. (2002). British Paramountcy in Kashmir 1876-1894 (p. 15). New Delhi: Atlantic Publishers.

Younghusband, F. (1996). Kashmir (p. 181). Srinagar: Gulshan Publishers. 